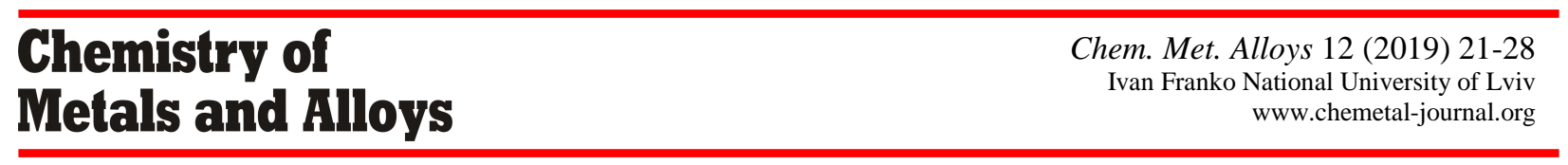

\title{
Crystal structure of $\mathrm{GdNi}_{3} \mathrm{Ga}_{9}$
}

\author{
Viktor TOPERTSER ${ }^{1}$, Romana-Iryna MARTYNIAK ${ }^{1}$, Nataliya MUTS $^{1}{ }^{*}$, Yaroslav TOKAYCHUK $^{1}$, \\ Roman GLADYSHEVSKII ${ }^{1}$ \\ ${ }^{1}$ Department of Inorganic Chemistry, Ivan Franko National University of Lviv, \\ Kyryla i Mefodiya St. 6, 79005 Lviv, Ukraine \\ *Corresponding author.Tel.+380-32-2394506; e-mail: natalia.muts@gmail.com
}

Received May 12, 2019; accepted June 18, 2019; available on-line January 1, 2020

https://doi.org/10.30970/cma12.0390

\begin{abstract}
The crystal structure of the $\mathrm{GdNi}_{3} \mathrm{Ga}_{9}$ compound was refined on $\mathrm{X}$-ray powder diffraction data collected for a sample of composition $\mathrm{Gd}_{7.7} \mathrm{Ni}_{23.1} \mathbf{G a}_{69.2}$. The phase composition determined by $\mathrm{X}$-ray diffraction was confirmed by energy-dispersive $\mathrm{X}$-ray spectroscopy. The refinement of the crystal structure of $\mathrm{GdNi}_{3} \mathrm{Ga}_{9}$ was carried using the structure model defined on $\mathrm{DyNi}_{3} \mathrm{Al}_{9}$ (Pearson symbol $h R 99$, space group $R 32$, $a=0.72624(1), c=2.74876(5) \mathrm{nm})$. The structure type $\mathrm{DyNi}_{3} \mathrm{Al}_{9}$ is intermediate between the $R_{0.67} \mathrm{Ni}_{2} \mathrm{Al}_{6}$ type in space group $P-6 \mathrm{~m} 2$ (statistical arrangement of rare-earth atoms and Al atom triangles), and the fully ordered structure type $\mathrm{ErNi}_{3} \mathrm{Al}_{9}$ with the same supercell and space group $\mathrm{R32}$.
\end{abstract}

\section{X-ray powder diffraction / Energy-dispersive X-ray spectroscopy / Crystal structure / GdNi $\mathbf{G a}_{9}$}

\section{Introduction}

The $R-\mathrm{Ni}-\mathrm{Ga}$ systems, where $R$ is a rare-earth metal (Sc, Y, La-Lu), are rich in intermetallic compounds, as more than 270 ternary compounds formed by these metals and crystallizing with some 50 different structure types and stoichiometries, have been reported [1,2]. $\mathrm{KHg}_{2}$ (Pearson symbol oI12, space group Imma), $\mathrm{W}_{2} \mathrm{CoB}_{2}$ (oI10, Immm), $\mathrm{PrNi}_{2} \mathrm{Al}_{3}$ (hP6, $P 6 / m m m), \mathrm{YNi}_{2} \mathrm{Al}_{3}(h P 18, P 6 / m m m), \mathrm{CeNi}_{3}(h P 24$, $P 6_{3} / m m c$ ), TiNiSi (oP12, Pnma), $\mathrm{MgCuAl}_{2}$ (oS16, Cmcm), $\mathrm{Ce}_{3} \mathrm{Ni}_{6} \mathrm{Si}_{2}$ (cI44, Im-3m), $\mathrm{YNiAl}_{4}$ (oS24, Cmcm), and $\mathrm{CaIn}_{2}\left(h P 6, \mathrm{~Pb}_{3} / m m c\right)$ are among the most common structure types for this kind of system [2]. A brief summary of crystallographic data for these structure types and their occurrence in $R-\mathrm{Ni}-\mathrm{Ga}$ systems is given in Table 1 .

A recent investigation of the $\mathrm{Yb}-\mathrm{Ni}-\mathrm{Ga}$ system revealed the existence of $\mathrm{Yb}_{0.67} \mathrm{Ni}_{2} \mathrm{Ga}_{6}$ [3], a new ternary compound in the Ga-rich region, which crystallizes with a partially disordered structure. This structure type, here referred to as $R_{0.67} \mathrm{Ni}_{2} \mathrm{Al}_{6}(h P 11$, $P-6 m 2$ ), was predicted during an investigation of the ordered superstructure type $\mathrm{ErNi}_{3} \mathrm{Al}_{9}(h R 78, R 32)$ [4] and first observed for three quaternary compositions $R_{0.67} T_{2} \mathrm{Ga}_{6-x} T t_{x}$, where $R$ is a rare earth, $T$ a transition metal and $T t$ a tetrelide (Ge or $\mathrm{Si}$ ) [5]. Crystallographic data for the compounds reported to crystallize with this disordered structure are listed in Table 2. In order to find other isostructural compounds, a series of alloys was synthesized. This work focuses on the results of the investigation of a sample of composition $\mathrm{Gd}_{7.7} \mathrm{Ni}_{23.1} \mathrm{Ga}_{69.2}$. Crystallographic data for known ternary compounds formed by $\mathrm{Gd}, \mathrm{Ni}$, and $\mathrm{Ga}$ [2] are summarized in Table 3.

\section{Experimental}

The $\mathrm{Gd}_{7.7} \mathrm{Ni}_{23.1} \mathrm{Ga}_{69.2}$ sample was synthesized by arcmelting chemically pure $(\geq 99.89$ mass $\%)$ elements under a purified argon atmosphere. The mass of the sample was $1 \mathrm{~g}$ and the mass loss during the preparation was less than $1 \%$ of the total mass. The alloy was annealed at $600^{\circ} \mathrm{C}$ for 88 days in an evacuated quartz ampoule, and subsequently quenched in cold water. The crystal structure was refined from an X-ray powder diffraction pattern recorded with a STOE Stadi $\mathrm{P}$ diffractometer $\left(\mathrm{Cu} K \alpha_{1}\right.$ radiation), using the program package FullProf Suite [7]. TYPIX [8] was used to identify the structure types and standardize the structural parameters. The elemental composition, qualitative and quantitative, was determined by energy-dispersive X-ray spectroscopy (EDS), using an INCA Energy 350 microanalysis system and a scanning electron microscope ZEISS EVO 40XVP. In order to verify the phase composition determined by X-ray powder diffraction, EDS analysis of the individual phases was conducted using an AZtecLive real-time chemical imaging device and an Ultim Max Silicon Drift Detector. 
Table 1 Most common structure types reported to form in $R-\mathrm{Ni}-\mathrm{Ga}$ systems [2]. Structure type branches and ordering variants are not distinguished and the homogeneity range may in exceptional cases reach one of the boundary binary systems.

\begin{tabular}{c|c|c|c}
\hline Structure type & Pearson symbol & Space group & $\begin{array}{c}\text { Number of } R-\mathrm{Ni}-\mathrm{Ga} \\
\text { systems }\end{array}$ \\
\hline $\mathrm{PrNi}_{2} \mathrm{Al}_{3}$ & $h P 6$ & $P 6 / m m m$ & 14 \\
$\mathrm{~W}_{2} \mathrm{CoB}_{2}$ & $o I 10$ & Immm & 14 \\
$\mathrm{CeNi}_{3}$ & $h P 24$ & $P 6_{3} / m m c$ & 13 \\
$\mathrm{KHg}_{2}$ & $o I 12$ & Imma & 13 \\
$\mathrm{TiNiSi}_{\mathrm{NNi}} \mathrm{Al}_{3}$ & $o P 12$ & $P$ mma & 13 \\
$\mathrm{YNiAl}_{4}$ & $h P 18$ & $\mathrm{Cm} / \mathrm{mmm}$ & 11 \\
$\mathrm{Ce}_{3} \mathrm{Ni}_{6} \mathrm{Si}_{2}$ & $o S 24$ & $I m-3 m$ & 10 \\
$\mathrm{CaIn}_{2}$ & $c I 44$ & $P 6_{3} / m m c$ & 9 \\
$\mathrm{MgCuAl}_{2}$ & $h P 6$ & $C m c m$ & 9 \\
\hline
\end{tabular}

Table 2 Compounds found to crystallize with $R_{0.67} \mathrm{Ni}_{2} \mathrm{Al}_{6}$-type structures $(h P 11, P-6 m 2)$.

\begin{tabular}{|c|c|c|c|c|}
\hline \multirow{2}{*}{ Compound } & \multicolumn{2}{|c|}{ Unit-cell parameters, $\mathrm{nm}$} & \multirow{2}{*}{$V, \mathrm{~nm}^{3}$} & \multirow{2}{*}{$\operatorname{Re}$} \\
\hline & $a$ & $c$ & & \\
\hline $\mathrm{Sc}_{0.67} \mathrm{Ni}_{2} \mathrm{Al}_{6}$ & 0.416403 & 0.90586 & 0.1360 & {$[6]$} \\
\hline $\mathrm{Y}_{0.67} \mathrm{Ni}_{2} \mathrm{Al}_{6}$ & 0.42038 & 0.91316 & 0.1398 & [6] \\
\hline $\mathrm{Gd}_{0.67} \mathrm{Ni}_{2} \mathrm{Al}_{6}$ & 0.42088 & 0.91494 & 0.1404 & {$[6]$} \\
\hline $\mathrm{Tb}_{0.67} \mathrm{Ni}_{2} \mathrm{Al}_{6}$ & 0.42008 & 0.91303 & 0.1395 & {$[6]$} \\
\hline $\mathrm{Dy}_{0.67} \mathrm{Ni}_{2} \mathrm{Al}_{6}$ & 0.42008 & 0.91262 & 0.1395 & {$[6]$} \\
\hline $\mathrm{Ho}_{0.67} \mathrm{Ni}_{2} \mathrm{Al}_{6}$ & 0.41980 & 0.91171 & 0.1391 & {$[6]$} \\
\hline $\mathrm{Er}_{0.67} \mathrm{Ni}_{2} \mathrm{Al}_{6}$ & 0.41939 & 0.91071 & 0.1387 & {$[6]$} \\
\hline $\mathrm{Tm}_{0.67} \mathrm{Ni}_{2} \mathrm{Al}_{6}$ & 0.41888 & 0.90983 & 0.1383 & [6] \\
\hline $\mathrm{Yb}_{0.67} \mathrm{Ni}_{2} \mathrm{Al}_{6}$ & 0.41890 & 0.90982 & 0.1383 & {$[6]$} \\
\hline $\mathrm{Lu}_{0.67} \mathrm{Ni}_{2} \mathrm{Al}_{6}$ & 0.41871 & 0.90905 & 0.1380 & [6] \\
\hline $\mathrm{Yb}_{0.67} \mathrm{Ni}_{2} \mathrm{Ga}_{6}$ & 0.41656 & 0.91557 & 0.1383 & {$[3]$} \\
\hline $\mathrm{Sm}_{0.67} \mathrm{Ni}_{2} \mathrm{Ga}_{6-x} \mathrm{Si}_{x}{ }^{a}$ & 0.41976 & 0.9159 & 0.1398 & {$[5]$} \\
\hline $\mathrm{Gd}_{0.67} \mathrm{Ni}_{2} \mathrm{Ga}_{6-x} \mathrm{Ge}_{x}{ }^{b}$ & 0.41856 & 0.9167 & 0.1391 & {$[5]$} \\
\hline $\mathrm{Y}_{0.60} \mathrm{Co}_{2} \mathrm{Ga}_{5.33} \mathrm{Ge}_{0.67}$ & 0.41822 & 0.9240 & 0.1400 & {$[5]$} \\
\hline
\end{tabular}

${ }^{a}$ refined composition $\mathrm{Sm}_{0.67} \mathrm{Ni}_{2} \mathrm{Ga}_{5.94} \mathrm{Si}_{0.06}$; ${ }^{b}$ composition from refinement $\mathrm{Gd}_{0.58} \mathrm{Ni}_{2} \mathrm{Ga}_{5} \mathrm{Ge}$, from chemical analysis $\mathrm{Gd}_{0.6} \mathrm{Ni}_{2} \mathrm{Ga}_{5.3} \mathrm{Ge}_{0.8}$

Table 3 Crystallographic data for known ternary compounds in the $\mathrm{Gd}-\mathrm{Ni}-\mathrm{Ga}$ system [2].

\begin{tabular}{|c|c|c|c|c|c|c|}
\hline \multirow{2}{*}{ Compound } & \multirow{2}{*}{ Structure type } & \multirow{2}{*}{$\begin{array}{c}\text { Pearson } \\
\text { symbol }\end{array}$} & \multirow{2}{*}{ Space group } & \multicolumn{3}{|c|}{ Unit-cell parameters, $\mathrm{nm}$} \\
\hline & & & & $a$ & $b$ & $c$ \\
\hline $\mathrm{Gd}_{3} \mathrm{Ni}_{6} \mathrm{Ga}_{2}$ & $\mathrm{Ce}_{3} \mathrm{Ni}_{6} \mathrm{Si}_{2}$ & cI44 & Im-3m & 0.8921 & - & - \\
\hline $\mathrm{GdNiGa}_{4}$ & $\mathrm{YNiAl}_{4}$ & $o S 24$ & $\mathrm{Cmcm}$ & 0.4093 & 1.5355 & 0.6548 \\
\hline $\mathrm{GdNi}_{3} \mathrm{Ga}_{2} \mathrm{rt}$ & $\mathrm{YNi}_{2} \mathrm{Al}_{3}$ & $h P 18$ & $P 6 / \mathrm{mmm}$ & 0.8737 & - & 0.4132 \\
\hline $\mathrm{GdNi}_{3} \mathrm{Ga}_{2} \mathrm{ht}$ & $\mathrm{PrNi}_{2} \mathrm{Al}_{3}$ & $h P 6$ & $P 6 / \mathrm{mmm}$ & 0.5086 & - & 0.4051 \\
\hline $\mathrm{GdNiGa}_{3}$ & $\mathrm{BaNiSn}_{3}$ & $t I 10$ & $I 4 m m$ & 0.4166 & - & 0.9960 \\
\hline $\mathrm{GdNi}_{2.72} \mathrm{Ga}_{0.28}$ & $\mathrm{CeNi}_{3}$ & $h P 24$ & $\mathrm{~Pb}_{3} / m m c$ & 0.5035 & - & 1.6340 \\
\hline $\mathrm{GdNiGa}_{2}$ & $\mathrm{NdNiGa}_{2}$ & $o S 16$ & Cmmm & 0.4120 & 1.7540 & 0.4082 \\
\hline $\mathrm{GdNiGa}$ & TiNiSi & $o P 12$ & Pnma & 0.6970 & 0.4329 & 0.7385 \\
\hline $\mathrm{GdNi}_{0.3} \mathrm{Ga}_{1.7}$ & $\mathrm{CaIn}_{2}$ & $h P 6$ & $\mathrm{PG}_{3} / m m c$ & 0.4357 & - & 0.7430 \\
\hline $\mathrm{GdNi}_{0.52} \mathrm{Ga}_{1.48}$ & $\mathrm{KHg}_{2}$ & $o I 12$ & Imma & 0.4375 & 0.7190 & 0.7570 \\
\hline $\mathrm{Gd}_{2} \mathrm{Ni}_{2} \mathrm{Ga}$ & $\mathrm{W}_{2} \mathrm{CoB}_{2}$ & $o I 10$ & Immm & 0.4197 & 0.5407 & 0.8383 \\
\hline $\mathrm{GdNi}_{0.8} \mathrm{Ga}_{0.2}$ & TII & $o S 8$ & $\mathrm{Cmcm}$ & 0.3780 & 1.0390 & 0.4297 \\
\hline
\end{tabular}




\section{Results and discussion}

The results of local and average EDS analysis of the $\mathrm{Gd}_{7.7} \mathrm{Ni}_{23.1} \mathrm{Ga}_{69.2}$ sample surface showed good agreement with the nominal composition (Table 4), as well as homogeneity of the sample (Fig. 1). The sample was found to contain three phases: a new ternary phase of composition $\mathrm{GdNi}_{3} \mathrm{Ga}_{9}$, the binary phase $\mathrm{Ni}_{2} \mathrm{Ga}_{3}$ (structure type $\mathrm{Ni}_{2} \mathrm{Al}_{3}$ ) and the ternary phase $\mathrm{GdNiGa}_{4}$ (structure type $\mathrm{YNiAl}_{4}$ ). The results of the EDS analysis of the individual phases of the $\mathrm{Gd}_{7.7} \mathrm{Ni}_{23.1} \mathrm{Ga}_{69.2}$ sample (Fig. 2) showed that the measured compositions of the phases are in good agreement with the theoretical ones (Table 5).

Based on our previous investigation of the $\mathrm{Yb}-\mathrm{Ni}-\mathrm{Ga}$ system [3], and the report on the Ge-containing sample of neighboring composition [5], we made a preliminary hypothesis assuming the presence of a disordered $R_{0.67} \mathrm{Ni}_{2} \mathrm{Al}_{6}$-type phase, space group $P-6 m 2$. The atomic coordinates of the initial model for the refinement of the structure of the new compound were taken from the $\mathrm{Yb}_{0.67} \mathrm{Ni}_{2} \mathrm{Ga}_{6}$ compound [3]. The occupancy of Wyckoff position $1 a$ by Gd atoms was fixed to 0.667 and that of the site in Wyckoff position $3 j$, occupied by Ga atoms, was fixed to 0.333 . The refinement proceeded to a Bragg factor of $R_{\mathrm{B}}=0.0692$ and the $R_{0.67} \mathrm{Ni}_{2} \mathrm{Al}_{6}$ model satisfactorily described the majority of the peaks found in the experimental diffraction pattern. However, a detailed analysis of the $2 \theta$ region $30-48^{\circ}$ (see inset of Fig. 3) showed that the experimental diffraction pattern contained at least two peaks (at $40.10^{\circ}$ and $41.33^{\circ}$ ) that were not described by the $R_{0.67} \mathrm{Ni}_{2} \mathrm{Al}_{6}$ model, which could indicate ordering of the atoms and formation of a superstructure.

Table 4 Results of average and local EDS analysis of the surface-the $\mathrm{Gd}_{7.7} \mathrm{Ni}_{23.1} \mathrm{Ga}_{69.2}$ sample.

\begin{tabular}{c|c|c|l|r|r}
\hline \multicolumn{2}{c|}{$\begin{array}{c}\text { Results of average EDS analysis of the surface of } \\
\text { the } \mathrm{Gd}_{7.7} \mathrm{Ni}_{23.1} \mathrm{Ga}_{69.2} \text { alloy (Spectrum 1) }\end{array}$} & \multicolumn{3}{|c}{$\begin{array}{c}\text { Results of local EDS analysis of the surface of } \\
\text { the } \mathrm{Gd}_{7.7} \mathrm{Ni}_{23.1} \mathrm{Ga}_{69.2} \text { alloy (Spectrum 2) }\end{array}$} \\
\hline Element & Weight fraction & Atomic fraction & Element & Weight fraction & Atomic fraction \\
\hline $\mathrm{Gd}$ & 16.66 & 7.85 & $\mathrm{Gd} L$ & 16.87 & 7.95 \\
$\mathrm{Ni}$ & 18.09 & 22.82 & $\mathrm{Ni} K$ & 18.40 & 23.23 \\
$\mathrm{Ga}$ & 65.25 & 69.33 & $\mathrm{Ga} K$ & 64.73 & 68.82 \\
\hline
\end{tabular}

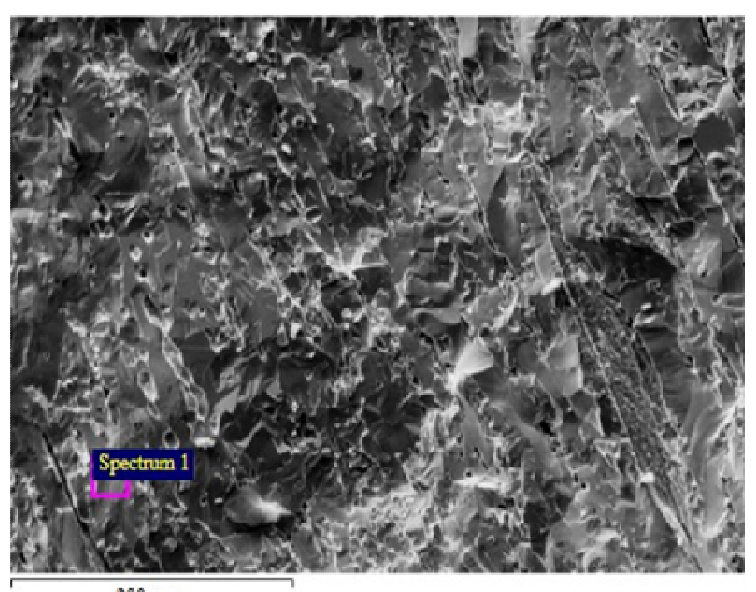

$200 \mu \mathrm{m}$

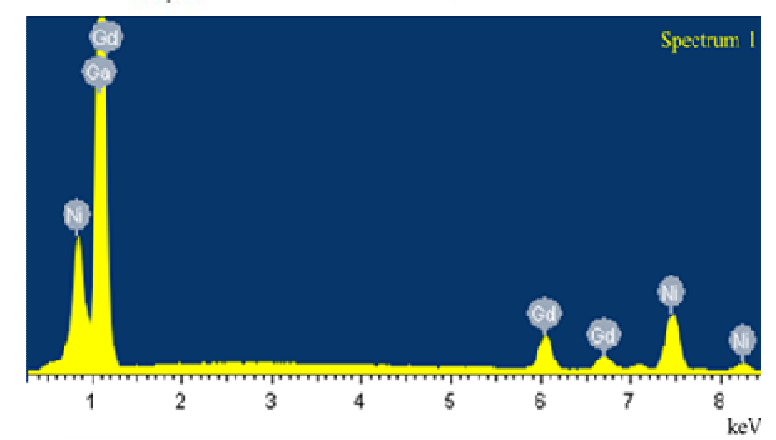

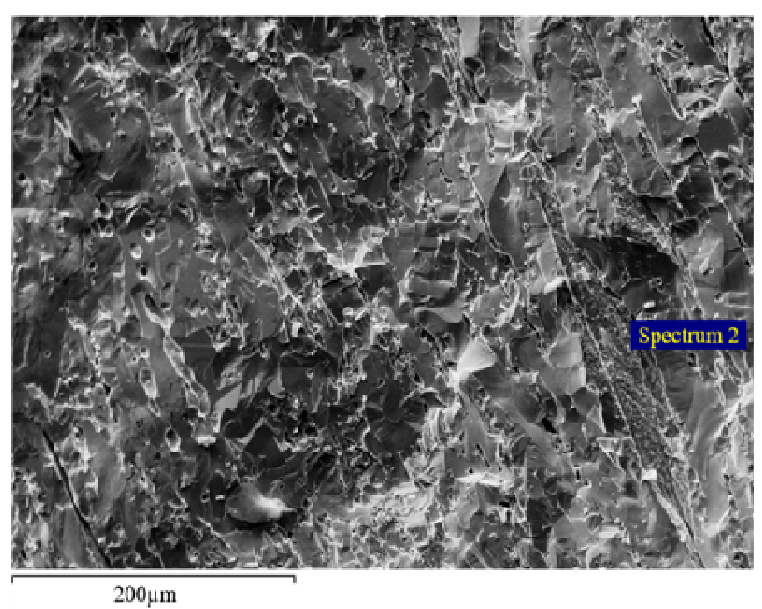

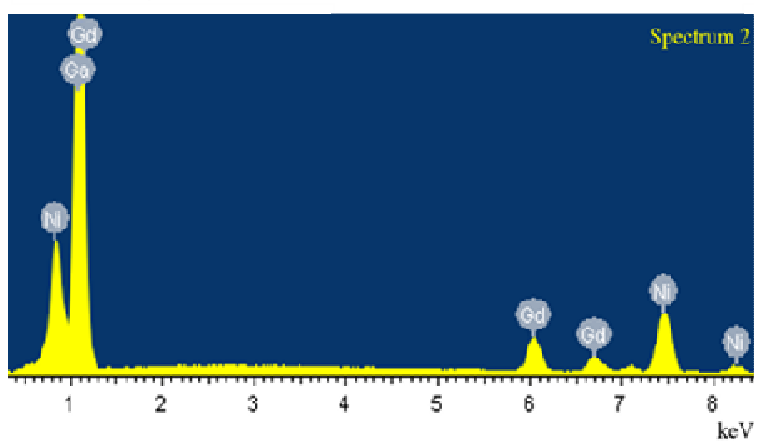

Fig. 1 Surface morphology at 500× magnification and EDS spectra of the $\mathrm{GdNi}_{3} \mathrm{Ga}_{9}$ alloy (Spectrum 1 average EDS analysis of the selected area; Spectrum 2 - local EDS analysis of a point at the surface). 
Table 5 Results of the EDS investigation of the phases in the $\mathrm{Gd}_{7.7} \mathrm{Ni}_{23.1} \mathrm{Ga}_{69.2}$ sample (theoretical composition in parentheses).

\begin{tabular}{c|l|c|c|c|c|c}
\hline Phase & \multicolumn{2}{|c|}{$\mathrm{GdNi}_{3} \mathrm{Ga}_{9}$} & \multicolumn{2}{c|}{$\mathrm{Ni}_{2} \mathrm{Ga}_{3}$} & \multicolumn{2}{c}{$\mathrm{GdNiGa}_{4}$} \\
\hline \multirow{2}{*}{ Element } & $\begin{array}{c}\text { Weight } \\
\text { fraction }\end{array}$ & $\begin{array}{c}\text { Atomic } \\
\text { fraction }\end{array}$ & $\begin{array}{c}\text { Weight } \\
\text { fraction }\end{array}$ & $\begin{array}{c}\text { Atomic } \\
\text { fraction }\end{array}$ & $\begin{array}{c}\text { Weight } \\
\text { fraction }\end{array}$ & $\begin{array}{c}\text { Atomic } \\
\text { fraction }\end{array}$ \\
\hline $\mathrm{Gd}$ & 16.84 & $7.94(7.69)$ & 0.53 & $0.22(0)$ & 31.95 & $16.78(16.67)$ \\
$\mathrm{Ni}$ & 17.85 & $22.57(23.08)$ & 34.61 & $38.71(40)$ & 11.81 & $16.61(16.67)$ \\
$\mathrm{Ga}$ & 65.31 & $69.49(69.23)$ & 64.86 & $61.07(60)$ & 56.24 & $66.61(66.66)$ \\
\hline
\end{tabular}
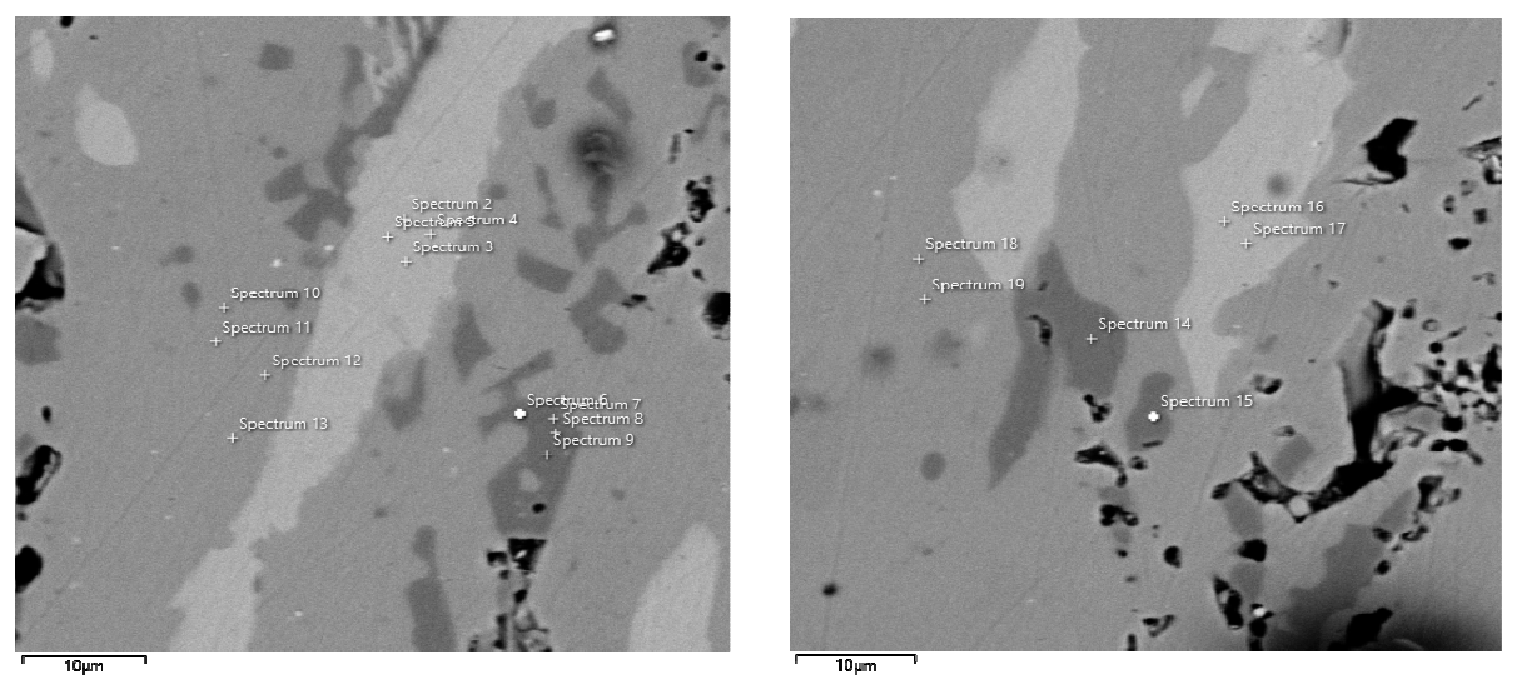

Fig. 2 Electron microscope photos of the $\mathrm{Gd}_{7.7} \mathrm{Ni}_{23.1} \mathrm{Ga}_{69.2}$ sample: gray matrix $-\mathrm{GdNi}_{3} \mathrm{Ga}_{9}\left(\mathrm{DyNi}_{3} \mathrm{Al}_{9}\right.$ type), dark gray regions $-\mathrm{Ni}_{2} \mathrm{Ga}_{3}\left(\mathrm{Ni}_{2} \mathrm{Al}_{3}\right)$, light gray regions $-\mathrm{GdNiGa}_{4}\left(\mathrm{YNiAl}_{4}\right)$.

As stated previously [4-6], the $R_{0.67} \mathrm{Ni}_{2} \mathrm{Al}_{6}$ structure is closely related to the structure types $\mathrm{ErNi}_{3} \mathrm{Al}_{9}$ (Pearson symbol hR78, space group R32) and $\mathrm{DyNi}_{3} \mathrm{Al}_{9}$ (Pearson symbol $h R 99$, space group $R 32$ ). Consequently, these models were used to try to fit the experimental diffraction pattern at the next step of our investigation. The atomic coordinates and isotropic displacement parameters refined for the $\mathrm{GdNi}_{3} \mathrm{Ga}_{9}$ compound assuming the partly ordered structure type $\mathrm{DyNi}_{3} \mathrm{Ga}_{9}$ are listed in Table 6 . The occupancies of all the sites susceptible to contain vacancies according to the structure type were refined, but some constraints were applied. Details of the Rietveld refinement of the quantitatively predominant phase in the $\mathrm{Gd}_{7.7} \mathrm{Ni}_{23.1} \mathrm{Ga}_{69.2}$ sample, $\mathrm{GdNi}_{3} \mathrm{Ga}_{9}$, are given in Table 7. The experimental, calculated and difference powder diffraction patterns for the $\mathrm{DyNi}_{3} \mathrm{Ga}_{9}$ model are shown in Fig. 3.

The low intensity peaks, which were not described by the $\mathrm{Yb}_{0.67} \mathrm{Ni}_{2} \mathrm{Al}_{6}$ model are satisfactorily described by the $\mathrm{DyNi}_{3} \mathrm{Al}_{9}$ (and $\mathrm{ErNi}_{3} \mathrm{Al}_{9}$ ) superstructure models, which confirms a tendency towards ordering for the structure of the $\mathrm{GdNi}_{3} \mathrm{Ga}_{9}$ compound. The significant occupancy of site $\operatorname{Gd} 2$ (0.394(4)), absent in the $\mathrm{ErNi}_{3} \mathrm{Al}_{9}$ type, excludes complete ordering. On the other hand, complete disorder of $\mathrm{Gd}$ atoms and $\mathrm{Ga}$ atom triangles (smaller unit cell) would correspond to
$\operatorname{occ}(\mathrm{Gd} 1)=\operatorname{occ}(\mathrm{Gd} 2)=0.667$, which is far from the refined values.

The structures types $R_{0.67} \mathrm{Ni}_{2} \mathrm{Al}_{6}, \quad \mathrm{DyNi}_{3} \mathrm{Al}_{9}$ and $\mathrm{ErNi}_{3} \mathrm{Al}_{9}$ are peculiar in the sense that the translation unit along the crystallographic direction [001] contains four successive atomic layers $R_{0.67} \mathrm{Al}-\mathrm{NiAl}_{2}-\mathrm{Al}-\mathrm{NiAl}_{2}$ (multiplied by 3 for the $R$ translation of the superstructures), which is illustrated in Fig. 4. The difference between the structures lies in the $R_{0.67} \mathrm{Al}$ layers. The $R_{0.67} \mathrm{Ni}_{2} \mathrm{Al}_{6}$ structure contains a statistical arrangement of $R$ atoms and $\mathrm{Al}$ atom triangles, whereas the arrangement of Dy atoms and $\mathrm{Al}$ atom triangles in $\mathrm{DyNi}_{3} \mathrm{Al}_{9}$ is partially ordered. The $\mathrm{ErNi}_{3} \mathrm{Al}_{9}$ structure type is characterized by full ordering of $\mathrm{Er}$ atoms and $\mathrm{Al}$ atom triangles (Fig. 5).

For the refinement of the structure of $\mathrm{GdNi}_{3} \mathrm{Ga}_{9}$ we assumed that each position $00,1 / 32 / 3$ and $2 / 31 / 3$ in the $R_{0.67} \mathrm{Ga}$ layers is occupied either by a $\mathrm{Gd}$ atom or a $\mathrm{Ga}_{3}$ triangle, and constrained the sums of the occupancies of the sites $\mathrm{Gd} 1$ and Ga7, and Gd2 and $\mathrm{Ga} 2$, to be equal to 1 . Vacancies excluded, the Ga:Gd ratio in the layers cannot exceed 3:2, otherwise too short Ga-Ga distances would occur between neighboring triangles. This implies an additional constraint on the site occupancies: $\operatorname{occ}(\mathrm{Gd} 1)+\operatorname{occ}(\mathrm{Gd} 2) / 2 \geq 1$. The refined value, 
$1.044(5)$, is close to unity. For the refinement of $\mathrm{DyNi}_{3} \mathrm{Al}_{9}$ [4], the occupancies were constrained to the stoichiometry 1:3:9, whereas for the refinement of $\mathrm{Gd}_{0.67} \mathrm{Ni}_{2} \mathrm{Ga}_{6-x} \mathrm{Ge}_{x}$, the total $\mathrm{Ga}+\mathrm{Ge}$ content was fixed to 6 atoms per formula unit, but the occupancy of the only $\mathrm{Gd}$ site was refined to $0.580(6)$, i.e. the composition of the layers containing the rareearth atoms was found to be $\mathrm{Gd}_{1.74} \square_{0.26}(\mathrm{Ga}, \mathrm{Ge})_{3}$. We believe that the composition of each layer is close to $\mathrm{Gd}_{2} \mathrm{Ga}_{3}$ and that the disorder is mainly the result of stacking faults, possibly favored by small deviations from the ideal composition. The result of the EDS analysis, which showed a slight excess of $\mathrm{Gd}$ with respect to the stoichiometric amount, supports the idea of partial replacement of $\mathrm{Ga}$ atom triangles by $\mathrm{Gd}$ atoms, but at the same time some $\mathrm{Ga}$ atoms would be replaced by $\mathrm{Ni}$ atoms in the intermediate slabs.

Table 6 Atomic coordinates and isotropic displacement parameters for the $\mathrm{GdNi}_{3} \mathrm{Ga}_{9}$ compound (structure type $\mathrm{DyNi}_{3} \mathrm{Al}_{9}$, Pearson symbol $h R 99$, space group $R 32, a=0.72624(1), c=2.74876(5) \mathrm{nm}$ ).

\begin{tabular}{c|c|c|c|c|c|c}
\hline \multirow{2}{*}{ Atom } & Wyckoff & \multicolumn{3}{|c|}{ Atomic coordinates } & \multirow{2}{*}{ Occupancy } & $B_{\text {iso. }}$ \\
\cline { 3 - 6 } & position & $x$ & $y$ & $z$ & $0.847(3)^{a}$ & $1.62(9)$ \\
$\left.\mathrm{nm}^{2}\right)$
\end{tabular}

${ }^{a} \mathrm{occ}(\mathrm{Gd} 1)+\operatorname{occ}(\mathrm{Ga} 7)$ was constrained to $1 ;{ }^{b} \mathrm{occ}(\mathrm{Gd} 2)+\operatorname{occ}(\mathrm{Ga} 2)$ was constrained to 1

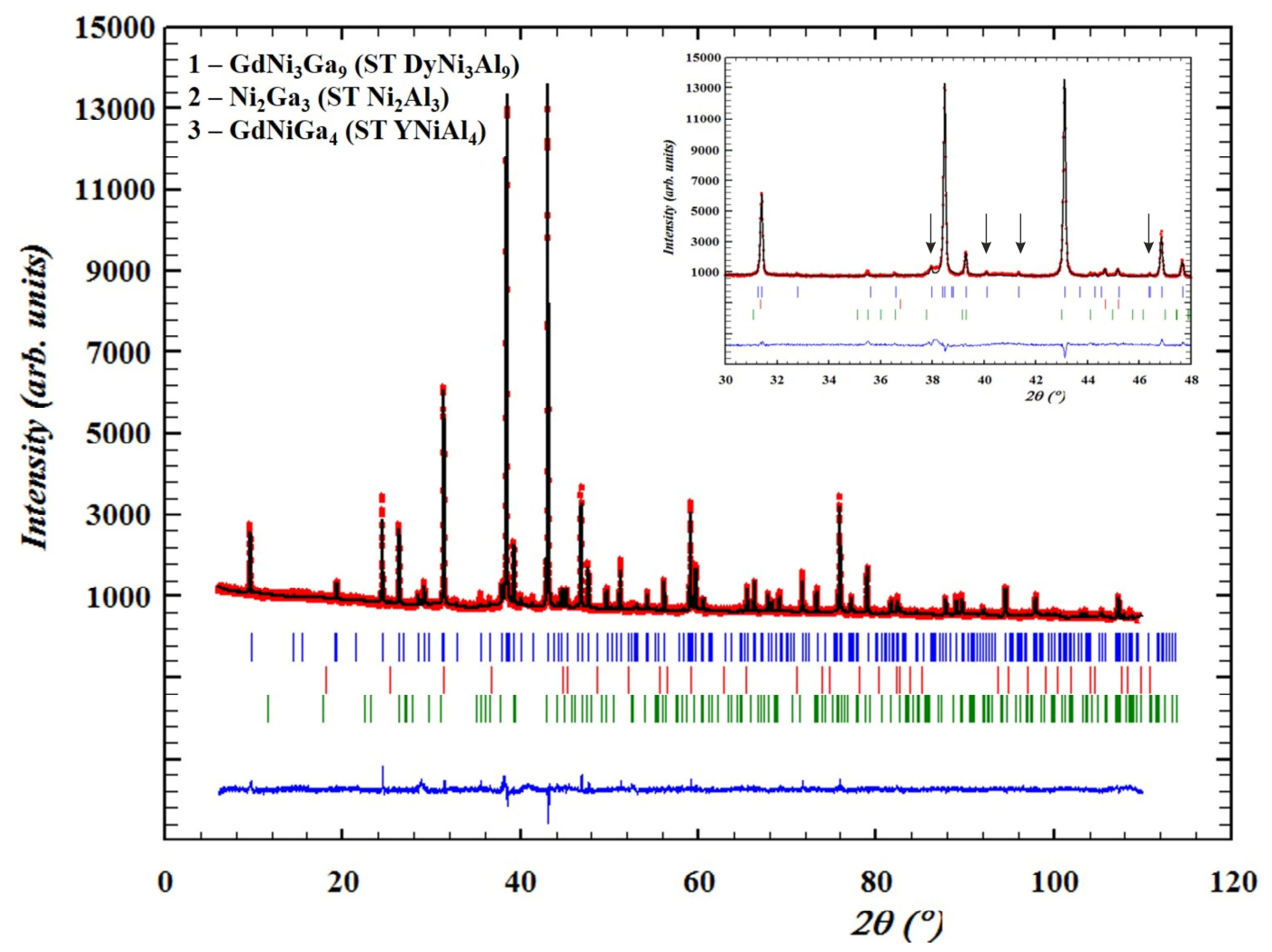

Fig. 3 Observed, calculated and difference (bottom) X-ray powder diffraction patterns for the $\mathrm{Gd}_{7.7} \mathrm{Ni}_{23.1} \mathrm{Ga}_{69.2}$ sample annealed at $600^{\circ} \mathrm{C}$ for 88 days; $\mathrm{Cu} K \alpha_{1}$ radiation $\left(\mathrm{GdNi}_{3} \mathrm{Ga}_{9}-93.6(7)\right.$ mass $\%$, DyNi ${ }_{3} \mathrm{Al}_{9}$ structure type; $\mathrm{Ni}_{2} \mathrm{Ga}_{3}-3.7(1)$ mass $\%, \mathrm{Ni}_{2} \mathrm{Al}_{3}$ structure type; $\mathrm{GdNiGa}_{4}-2.7(1)$ mass $\%, \mathrm{YNiAl}_{4}$ structure type). Arrows on the inset indicate the superstructure lines. 


\section{$\mathrm{Yb}_{0.67} \mathrm{Ni}_{2} \mathrm{Al}_{6} \quad \mathrm{DyNi}_{3} \mathrm{Al}_{9} \quad \mathrm{ErNi}_{3} \mathrm{Al}_{9}$}

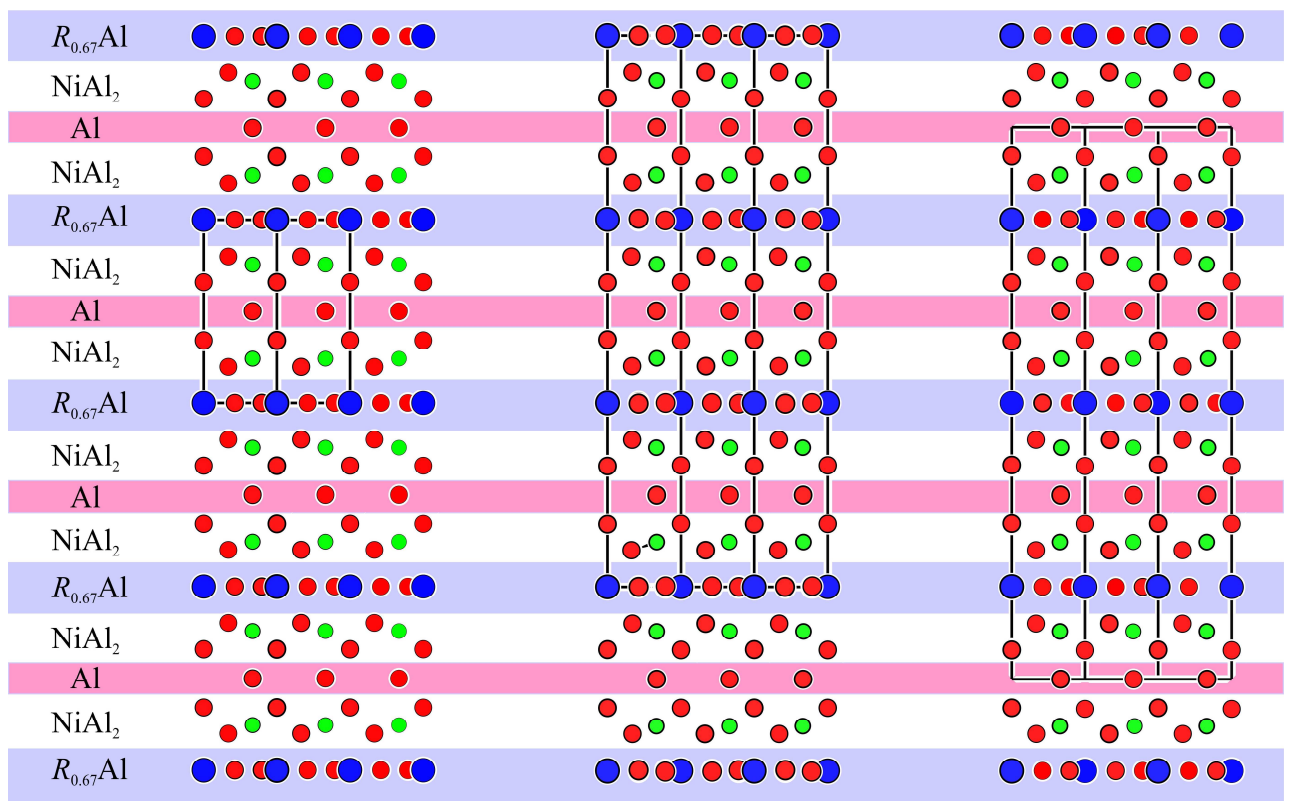

Fig. 4 Representation of the relationship between the $\mathrm{Yb}_{0.67} \mathrm{Ni}_{2} \mathrm{Al}_{6}$ (Pearson symbol $h P 11$, space group $P-6 m 2$ ), DyNi $\mathrm{Al}_{9}$ (Pearson symbol $h R 99$, space group $R 32$ ) and $\mathrm{ErNi}_{3} \mathrm{Al}_{9}$ (Pearson symbol $h R 78$, space group $R 32)$ structure types.
$\mathrm{Yb}_{0.67} \mathrm{Ni}_{2} \mathrm{Al}_{6}$
$\mathrm{DyNi}_{3} \mathrm{Al}_{9}$
$\mathrm{ErNi}_{3} \mathrm{Al}_{9}$
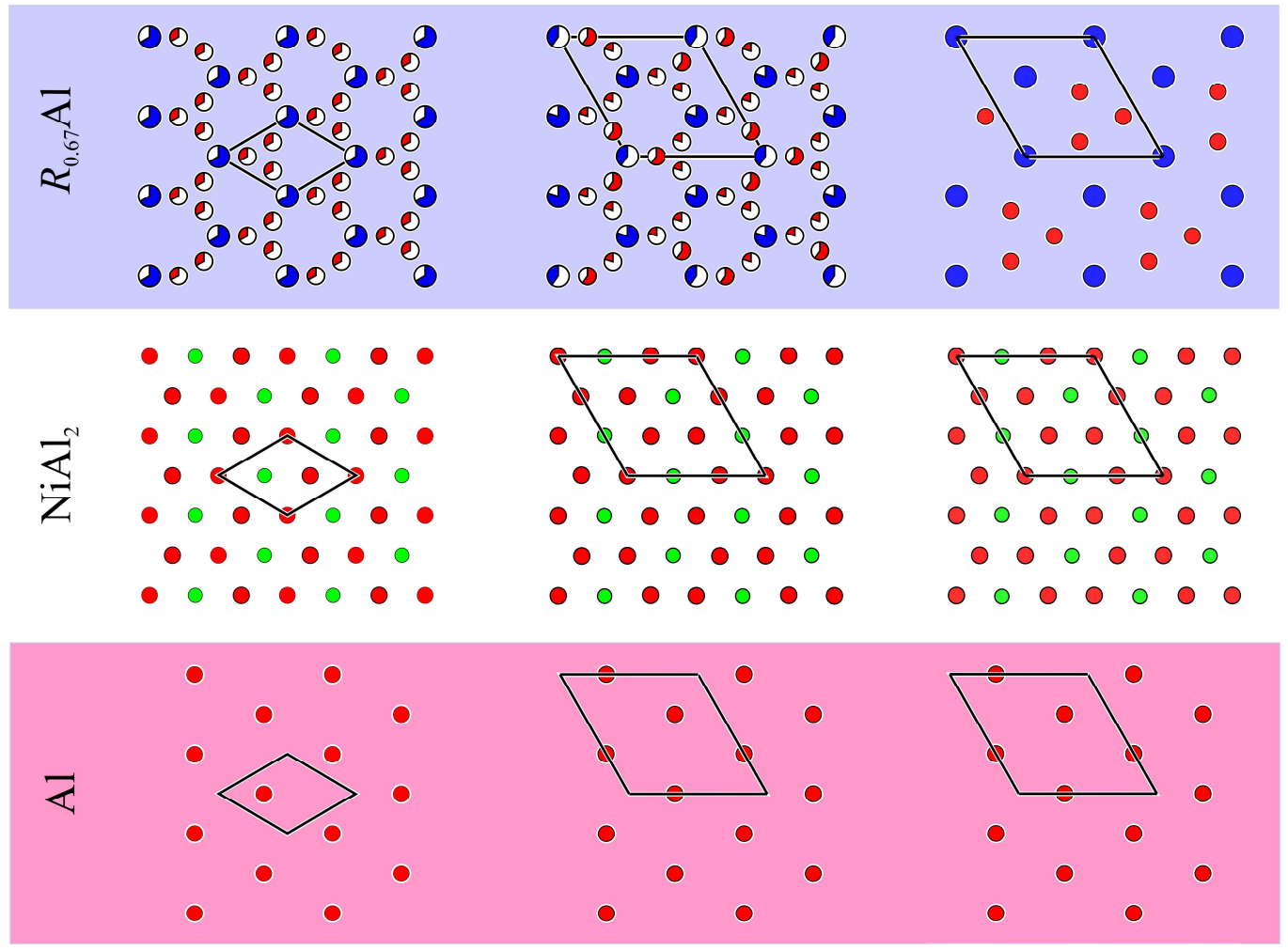

Fig. $5 \mathrm{~A}$ closer look at the atomic layers of the $\mathrm{Yb}_{0.67} \mathrm{Ni}_{2} \mathrm{Al}_{6}, \mathrm{DyNi}_{3} \mathrm{Al}_{9}$ and $\mathrm{ErNi}_{3} \mathrm{Al}_{9}$ structure types. The translation units are indicated by dotted lines. Colored parts of circles show the probability of the position to be occupied. 
Table 7 Experimental details of the structure refinement of $\mathrm{GdNi}_{3} \mathrm{Ga}_{9}$.

\begin{tabular}{c|c}
\hline Sample & $\mathrm{Gd}_{7.7 \mathrm{Ni}_{23.1} \mathrm{Ga}_{69.2}}$ \\
Compound & $\mathrm{GdNi}_{3} \mathrm{Ga}_{9}$ \\
Structure type & $\mathrm{DyNi}_{3} \mathrm{Al}_{9}$ \\
Pearson symbol & $h R 99$ \\
Space group & $R 32$ \\
Cell parameters: & \\
$a, \mathrm{~nm}$ & $0.72624(1)$ \\
$c, \mathrm{~nm}$ & $2.74876(5)$ \\
Cell volume $V, \mathrm{~nm}^{3}$ & $1.25554(4)$ \\
Formula units per unit cell $Z$ & 6 \\
Density $D_{x}$, g/cm & \\
Preferred orientation $[$ direction] & 8.937 \\
$\theta$ range ${ }^{\circ}$ [step] & $0.971(4)[110]$ \\
Number of measured reflections & $6-110.625^{\circ}[0.015]$ \\
Number of refined parameters & 6976 \\
FWHM parameters: & 38 \\
$U$ & \\
$V$ & $0.019(2)$ \\
$W$ & $-0.009(2)$ \\
$R_{\mathrm{p}} / R_{\text {wp }}$ & $0.0106(5)$ \\
$R_{\text {exp }} / \chi^{2}$ & $0.621(8)$ \\
Mixing parameter $\eta$ & $0.091(4)$ \\
Asymmetry parameters & $9.89 / 16.8$ \\
Reliability factors: & $3.81 / 5.07$ \\
$R_{\mathrm{B}} / R_{F}$ & $3.57 / 2.01$ \\
\hline
\end{tabular}

The crystal structures of the $R \mathrm{Ni}_{3} \mathrm{Al}_{9}$ compounds, where $R$ is $\mathrm{Gd}$ or Er were found to belong to the rhombohedral $\mathrm{ErNi}_{3} \mathrm{Al}_{9}$ type, whereas the compounds where $R$ is $\mathrm{Y}$ or Dy were refined with the partly disordered $\mathrm{DyNi}_{3} \mathrm{Al}_{9}$ type [4]. It should be noted that these compounds are the only ones so far reported to crystallize in the $\mathrm{ErNi}_{3} \mathrm{Al}_{9}$ and $\mathrm{DyNi}_{3} \mathrm{Al}_{9}$ structure types, respectively. Another partly ordered derivative with a larger supercell was reported for $\mathrm{Dy}_{0.62} \mathrm{Ni}_{2} \mathrm{Ga}_{5.25} \mathrm{Ge}(h P 60, P 31 c)$ [5].

The refinement of the structure of $\mathrm{Gd}_{0.67} \mathrm{Ni}_{2} \mathrm{Ga}_{6-x} \mathrm{Ge}_{x}$ on single-crystal data was performed in the disordered model $R_{0.67} \mathrm{Ni}_{2} \mathrm{Al}_{3}$ to a reliability factor of $R=0.027$ [5]. The exact amount of Ge could not be determined from X-ray diffraction, but the chemical analysis indicated a composition close to $\mathrm{Gd}_{0.6} \mathrm{Ni}_{2} \mathrm{Ga}_{5.3} \mathrm{Ge}_{0.8}$. As mentioned above, the refinement showed vacancies on the $\mathrm{Gd}$ site. No attempt was to our knowledge made to synthesize an analogue without $\mathrm{Ge}$. Consecutive $R_{0.67} \mathrm{Ga}$ layers in these structures are separated by $\sim 9 \AA$ thick slabs and it is easy to imagine that complete order is difficult to achieve and that the degree of disorder in the structure is very sensitive to the experimental conditions. A similar situation was observed for $\mathrm{Yb}_{0.67} \mathrm{Ni}_{2} \mathrm{Al}_{3}$, which was successfully refined assuming full disorder [6], but for which a supercell corresponding to partial or complete order has sometimes been reported [2].

Based on the results established in this work (both $\mathrm{X}$-ray powder diffraction data and EDS analysis), we can state that there exists a ternary equilibrium between the binary phase $\mathrm{Ni}_{2} \mathrm{Ga}_{3}$ (structure type $\left.\mathrm{Ni}_{2} \mathrm{Al}_{3}, h P 5, P-3 m 1\right)$, the ternary phase $\mathrm{GdNiGa}_{4}$ $\left(\mathrm{YNiAl}_{4}, o S 108, \quad C m c m\right)$ and the new ternary compound $\mathrm{GdNi}_{3} \mathrm{Ga}_{9}\left(\mathrm{DyNi}_{3} \mathrm{Al}_{9}, h R 99, R 32\right)$ in the Gd-Ni-Ga ternary system at $600^{\circ} \mathrm{C}$.

\section{Conclusions}

The $\mathrm{GdNi}_{3} \mathrm{Ga}_{9}$ compound belongs to the $\mathrm{DyNi}_{3} \mathrm{Al}_{9}$-type structure, which is a partially ordered variant of the fully ordered structure type $\mathrm{ErNi}_{3} \mathrm{Al}_{9}$, and the disordered $R_{0.67} \mathrm{Ni}_{2} \mathrm{Al}_{6}$ type. This is the third compound, after $\mathrm{DyNi}_{3} \mathrm{Al}_{9}$ and $\mathrm{YNi}_{3} \mathrm{Al}_{9}$, found to crystallize with a $\mathrm{DyNi}_{3} \mathrm{Al}_{9}$-type structure.

\section{Acknowledgements}

The authors would like to thank the team of Oxford Instruments Czech Republic for providing the possibility to use their equipment, as well as Dr. S. Korniy, senior research fellow at the Karpenko Physico-Mechanical Institute of NAS of Ukraine for his assistance with the SEM investigations.

This work was supported by the Ministry of Education and Science of Ukraine (grant No. 0118U003609). 


\section{References}

[1] L.O. Wasylechko, Yu.N. Grin, A.A. Fedorchuk, J. Alloys Comp. 219 (1995) 222-224.

[2] P. Villars, K. Cenzual (Eds.), Pearson's Crystal Data - Crystal Structure Database for Inorganic Compounds, Release 2016/17, ASM International, Materials Park (OH), 2016.

[3] M. Boyko, N. Muts, V. Hlukhyy, T. Fässler, R. Gladyshevskii, Coll. Abstr. XIII Int. Conf. Chem. Intermet. Compd., Lviv, 2016, p. 94.

[4] R. Gladyshevskii, K. Cenzual, H.D. Flack, E. Parthé, Acta Crystallogr. B 49 (1993) 468-474.
[5] M.A. Zhuravleva, X.Z. Chen, X. Wang, A.J. Schultz, J. Ireland, C.K. Kannewurf, M.G. Kanatzidis, Chem. Mater. 14 (2002) 3066-3081.

[6] O. Matselko, S. Pukas, Yu. Lutsyshyn, R. Gladyshevskii, D. Kaczorowski, J. Solid State Chem. 198 (2013) 50-56.

[7] J. Rodriguez-Carvajal, Commission on Powder Diffraction (IUCr) Newsletter 26 (2001) 12-19.

[8] E. Parthé, L. Gelato, B. Chabot, M. Penzo, K. Cenzual, R. Gladyshevskii, TYPIX Standardized Data and Crystal Chemical Characterization of Inorganic Structure Types, 4 vols., Springer Verlag, Berlin, 1993-4; electronic version 1996. 